\title{
Acute and Sub-acute Toxicities of Thai Silkworm Powder (Bombyx mori Linn.) From Three Races in Male Wistar Rats and In vitro Antioxidant Activities
}

\author{
Surapong Rattana ${ }^{1 *}$, Teeraporn Katisart ${ }^{2}$, Bunleu Sungthong ${ }^{3}$, Chirapha Butiman ${ }^{4}$
}

\section{Surapong Rattana ${ }^{1 *}$, Teeraporn Katisart ${ }^{2}$, Bunleu Sungthong ${ }^{3}$, Chirapha Butiman ${ }^{4}$}

\begin{abstract}
'Department of Biology, Faculty of Science, Mahasarakham University, Maha Sarakham, 44150, THAILAND. 2Department of Biology, Faculty of Science, Mahasarakham University, Maha Sarakham, 44150, THAILAND. ${ }^{3}$ Pharmaceutical Chemistry and Natural Products Research Unit, Faculty of Pharmacy, Mahasarakham University, Maha Sarakham, 44150, THAILAND.

${ }^{4}$ Silk Innovation Center, Mahasarakham University, Maha Sarakham, 44150, THAILAND.
\end{abstract}

Correspondence

Surapong Rattana, Department of Biology, Faculty of Science, Mahasarakham University, Maha Sarakham, 44150, THAILAND

Phone number.: +6643-754245

E-mail: rattanasurapong@gmail.com

History

- Submission Date: 17-04-2017;

- Review completed: 13-05-2017;

- Accepted Date: 18-05-2017.

DOI : 10.5530/pj.2017.4.87

Article Available online

http://www.phcogj.com/v9/i4

\section{Copyright}

(C) 2017 Phcog.Net. This is an openaccess article distributed under the terms of the Creative Commons Attribution 4.0 International license.

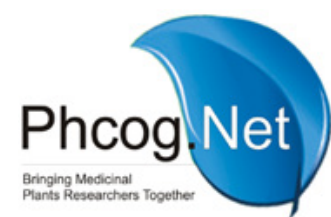

\begin{abstract}
Background: The silkworm powder from Japanese and Korean races has a high biological activity. However, there was less scientific evidence regarding bioactivities in Thai silkworm races. Objective: This research was interested in toxicity and antioxidant activities of Thai silkworm races. Material and methods: The $5^{\text {th }}$ instar, $3^{\text {rd }}$ day of growth stage of Thai traditional silkworm (Nanglai, Nangnoi and Samrong races) were lyophilized by freeze dryer and ground as silkworm powder. The acute and sub-acute toxicities studies were carried out in male Wistar rats. The antioxidant capacities of silkworm powder were investigated with DPPH, ABTS and FRAP methods. Results: The acute toxicity in rats by single dose oral administration show that the high dose at a concentration of 2,000 $\mathrm{mg} / \mathrm{kg} \mathrm{b} . \mathrm{w}$. did not have toxicity in rats. The sub-acute toxicity in rats by oral administration showed that the high dose concentration at $2,000 \mathrm{mg} / \mathrm{kg}$ body weight for 6 weeks had no toxicity in all group either. In addition, the hematological parameters and lipid profiles of treated group and control groups were not significantly different. The antioxidant study showed that silkworm powders were not significant difference in all groups of samples in three assays (DPPH, ABTS and FRAP). However, significant difference had been found in comparison to ascorbic acid $(p<0.05)$. Conclusion: Silkworm powder from three races of Thai silkworm did not produce any toxicity in male rats. In addition, the silkworm powder also exhibited antioxidant activities. Keywords: Silkworm, toxicities, hematological parameters, lipid profile, antioxidant activities.
\end{abstract}

\section{INTRODUCTION}

The biological activities of silkworm such as antihypertensive, ${ }^{1}$ anticancer, ${ }^{2}$ antibacterial, ${ }^{3}$ antiviral, ${ }^{4}$ antioxidant $^{5}$ and hepatoprotective activities $^{6}$ have been reported. Mulberry silkworm (Bombyx mori L.) has been reared in especially the northeastern part of Thailand for longtime. ${ }^{7}$ Silkworms are consumed mostly as functional food and pharmaceuticals for diabetes mellitus patient in Korea, China, and Japan. ${ }^{8}$ The major functional compound of silkworm powder was 1-deoxynojirimycin (DNJ) acting as alpha-glucosidase inhibitor. ${ }^{9}$ Therefore, the result from previous studies showed that silkworm powders were tended to be potential functional food. The safety of silkworm were still limited that only Korean silkworm races had been reported. ${ }^{8}$ However, Thai silkworm races had no scientific data regarding the safety for consumption. In order to make Thai silkworm powder widely used as food product, the safety should be investigated. This study was aimed to investigated the acute and sub-acute toxicities in male Wistar rat and in vitro antioxidant activities of three Thai silkworm races.

\section{MATERIALS AND METHODS}

\section{Chemicals}

Reagents of high quality were obtained from SigmaAldrich Chemical (St Louis, MO). Other chemical of analytical grade were purchased from Carlo Erba, Italy and Merck, Germany.

\section{Preparation of silkworm powder}

Three varieties of Thai mulberry silkworms including Nangnoi, Nanglai, and Samrong were reared at Silk Innovation Center, Mahasarakham University, Thailand. Identifications of silkworm races were performed with regard to the Queen Sirikit Department of Sericulture protocol. The $5^{\text {th }}$ instar, $3^{\text {rd }}$ day silk larvae were prepared according to the study of Ryu et al. ${ }^{10}$ The silkworms were then freeze-dried and ground in order to obtain fine powders. Silkworm powders were kept in freezer before use.

\section{Animals}

Male albino Wistar rats with weight of 150-200 g were purchased from the National Laboratory Animal Centre (NLAC), Mahidol University, Thailand. The rats were housed under standard environmental

Cite this article : Rattana S, Katisart T, Sungthong B, Butiman C. Acute and Sub-acute Toxicities of Thai Silkworm Powder (Bombyx mori Linn.) From Three Races in Male Wistar Rats and In vitro Antioxidant Activities. Pharmacog J. 2017;9(4):541-5. 
conditions (at $25 \pm 2{ }^{\circ} \mathrm{C}, 40-60 \%$ humidity with $12 \mathrm{~h}$ light $/ 12 \mathrm{~h}$ dark cycle).${ }^{11}$ All animals were given a standard laboratory diet with access to water ad libitum. The experimental protocol and the experiments performed on the rats were approved by the Institutional Animal Care and Use Ethic Committee, Mahasarakham University, Thailand (License No. 0015/2011).

\section{Acute toxicity test}

The rats were divided into 10 groups, 6 rats per group, were fasted overnight $(12 \mathrm{~h})$ and weighed. The doses of silkworm powder from 3 races were calculated according to the body weight of fasted animals and administered at doses of 1000, 1500 and $2000 \mathrm{mg} / \mathrm{kg}$ body weight. The animals were regularly and individually observed for behavioral changes and general toxicity signs after dosing for the first $24 \mathrm{~h}$, with special attention being given during the first $4 \mathrm{~h}$. Thereafter, observation was continued daily for a total of 14 days. Mortality, body weights, bizarre behavior and abnormal sign including seizures, urination, vomiting, anorexia or depression were recorded. ${ }^{12}$

\section{Sub-acute toxicity test}

The rats were divided into 10 groups, 6 rats per group, were treated orally with silkworm powder (two days per dose) for 6 weeks. Silkworm powders were administered at $2000 \mathrm{mg} / \mathrm{kg}$ body weight in each silkworm races. Mortality, body weights and blood glucose level were recorded for every week. Hematological values and lipid profile were recorded at last week. ${ }^{12}$

\section{Antioxidant activity}

DPPH radical scavenging assay - The test was carried out using the 1,1-diphenyl-2-picryl hydrazyl (DPPH) free radical scavenging assay. The free radical scavenging activity of the silkworm powder and standard ascorbic acid solution in absolute ethanol were determined based on their ability to react with the DPPH free radical..$^{13}$ A $750 \mu \mathrm{L}$ aliquot of silkworm powder $(10-1,000 \mu \mathrm{g} / \mathrm{mL}$, dissolved in $10 \%$ DMSO and filtered) was added into $750 \mu \mathrm{L}$ of DPPH in absolute ethanol $(152 \mu \mathrm{M})$. After incubation at room temperature in the dark condition for $20 \mathrm{~min}$, the absorbance of each solution was determined at $517 \mathrm{~nm}$ using 96-well plates with microtiter plate reader (BMG LABTECH GmbH, Ortenberg, Germany). The results were presented as a percentage of inhibition as follows:

$$
\text { \%inhibition }=\left[\left(\mathrm{A}_{\text {control }}-\mathrm{A}_{\text {sample }}\right) / \mathrm{A}_{\text {control }}\right] \times 100
$$

Where $\mathrm{A}_{\text {control }}$ was an absorbance of DPPH solution without sample. $\mathrm{A}_{\text {sample }}$ was an absorbance of DPPH solution with sample.

The inhibitory concentration of the sample requires scavenging DPPH radical by $50 \%\left(\mathrm{IC}_{50}\right.$ value $)$ and obtaining a linear regression analysis of a calibration curve plotting, \%inhibition versus concentration.

ABTS radical scavenging assay - 2,2'-azino-bis (3-ethylbenzthiazoline6-sulphonic acid) (ABTS) diammonium salt radical cationic decolorization test was performed using spectrophotometric method from the previous studied ${ }^{14}$ with slight modification. The ABTS stock solution was prepared by mixing $88 \mu \mathrm{L}$ of $140 \mathrm{mM}$ potassium persulfate $\left(\mathrm{K}_{2} \mathrm{~S}_{2} \mathrm{O}_{8}\right)$ with $5 \mathrm{~mL}$ of $7 \mathrm{mM}$ of ABTS stock solution (pH 7.4). The working ABTS reagent was prepared by diluting the stock solution with ethanol to obtain absorbance of $0.7 \pm 0.05$ at $734 \mathrm{~nm}$. The test concentrations of standard ascorbic acid, silkworm powders were prepared in the same manner as previously described in DPPH assay. The ABTS working solution $(100 \mu \mathrm{L})$ with equal volume of ethanol served as a control. The reaction mixtures were incubated at room temperature for $30 \mathrm{~min}$. The absorbance of each solution was determined at $734 \mathrm{~nm}$ using 96-well plates with microtiter plate reader (BMG LABTECH GmbH, Ortenberg, Germany). The results were expressed as percentage of inhibition as follows:

$$
\text { \%inhibition }=\left[\left(\mathrm{A}_{\text {control }}-\mathrm{A}_{\text {sample }}\right) / \mathrm{A}_{\text {control }}\right] \times 100
$$

Where $\mathrm{A}_{\text {control }}$ was an absorbance of ABTS solution with ethanol. $\mathrm{A}_{\text {sample }}$ was an absorbance of ABTS solution with sample.

The effective concentration of sample requires to scavenge ABTS radical by $50 \%\left(\mathrm{EC}_{50}\right.$ value $)$ and obtaining by a linear regression analysis of a calibration curve plotting \% inhibition versus concentration.

FRAPassay (Ferricreducingantioxidantpower)-FRAP assay was carried out with some modification from Benzie and Strain. ${ }^{15}$ The FRAP reagent was prepared from $300 \mathrm{mM}$ acetate buffer ( $\mathrm{pH}$ 3.6), $20 \mathrm{mM}$ ferric chloride and $10 \mathrm{mM} \mathrm{2,4,6-Tris(2-pyridyl)-s-triazine} \mathrm{(TPTZ)} \mathrm{in} 40 \mathrm{mM}$ $\mathrm{HCl}$. All 3 solutions were mixed together in the ratio of 10:1:1 (v/v/v), respectively. The FRAP reagent was freshly prepared daily prior to use. A total of $30 \mu \mathrm{L}$ sample was added to $270 \mu \mathrm{L}$ of the FRAP reagent and mixed well. After $30 \mathrm{~min}$ at room temperature incubation, the absorbances of final solutions were subsequently measured at $593 \mathrm{~nm}$ in 3 replicates using microplate reader. The antioxidant capacity of sample was calculated and compared with trolox calibration curve, and expressed as $\mu \mathrm{mol}$ trolox equivalent (TE) per gram of silkworm powders.

\section{Statistical analysis}

All data were expressed as mean \pm standard error of mean (SEM). The investigated parameters of each sample were evaluated in triplicate. The statistical analyses of the data were carried out by analysis of variance (ANOVA), using the statistical package SPSS 15 and the Duncan's multiple range test (DMRT) to indicate the statistical difference at $P$ - value $<0.05$.

\section{RESULTS}

\section{The acute and sub-acute toxicity}

For acute toxicity study, the rats were single administered silkworm powder from 3 races at dose of 1,000, 1,500 and 2,000 mg/kg b.w. The mortality and behavioral sign and symptoms of toxicity were observed within $24 \mathrm{~h}$ and further for 14 days. During this experiment, rats body weights were measured as shown in Table 1 . The result indicated that no dead animals and toxicity symptoms were found. In additions, the body weights of control and treated rats tended to increase week by week without significant difference among groups.

For sub-acute toxicity, the rats were administered every two days with silkworm powder from three races at a dose of 2,000 mg/kg b.w. During the experiment, body weight and blood glucose levels were measured weekly for 6 weeks (Table 2 and 3). At the end of the experiments, blood chemistry parameters and hematological values were analyzed (Table 4 and 5). The results showed that body weights of control and treated rats were not different but tend to be increased week by week. The body weights among control and silkworm powder treated rats were not significantly different.

On the other hands, blood glucose levels and blood chemistry parameters of the control and silkworm powder treated rats were not different. This finding suggested that silkworm powder did not alter organ system function in male rats and did not exhibit any toxicity in rats.

\section{Antioxidant activities}

The results of antioxidant activities of three races silkworm powders tested by DPPH, ABTS and FRAP methods were showed in Table 6 . The antioxidant study indicated that the capacities of silkworm powders were not significant difference in all groups of samples in three assays $(\mathrm{DPPH}$, ABTS and FRAP). However, significant difference has been found comparing with ascorbic acid ( $p>0.05)$. it was found that Thai silkworm from three races have less antioxidant capacity than those of ascorbic acid. 
Table 1: Body weight $(\mathrm{g})$ of rats in the acute toxicity study $(\mathrm{n}=6)$

\begin{tabular}{cccc}
\hline Treatment & Week0 & Week1 & Week2 \\
\hline Nanglai-1000 mg & $190.66 \pm 6.00$ & $200.00 \pm 8.16$ & $215.00 \pm 7.63$ \\
Nanglai-1500 mg & $181.66 \pm 3.07$ & $200.00 \pm 5.77$ & $210.00 \pm 4.47$ \\
Nanglai-2000 mg & $171.66 \pm 6.45$ & $180.00 \pm 4.08$ & $193.33 \pm 4.65$ \\
Sumrong-1000 mg & $188.33 \pm 4.08$ & $206.66 \pm 4.47$ & $230.00 \pm 2.88$ \\
Sumrong-1500 mg & $180.00 \pm 4.65$ & $183.33 \pm 3.41$ & $200.00 \pm 3.65$ \\
Sumrong-2000 mg & $185.00 \pm 4.65$ & $198.33 \pm 5.00$ & $216.66 \pm 4.65$ \\
Nangnoi-1000 mg & $181.66 \pm 2.88$ & $221.66 \pm 4.08$ & $251.66 \pm 3.41$ \\
Nangnoi-1500 mg & $188.33 \pm 4.08$ & $206.66 \pm 4.47$ & $228.33 \pm 4.47$ \\
Nangnoi-2000 mg & $191.66 \pm 5.32$ & $208.33 \pm 3.41$ & $221.66 \pm 4.47$ \\
normal (0.5\% Tween 80) & $186.66 \pm 3.41$ & $201.66 \pm 3.41$ & $218.33 \pm 3.41$ \\
\hline
\end{tabular}

Table 2: Body weight $(g)$ of rats in sub-acute toxicity study $(n=6)$

\begin{tabular}{cccccccc}
\hline $\begin{array}{c}\text { Treatment } \\
\text { 2,000 } \mathrm{mg} / \mathrm{kg} \text { b.w. }\end{array}$ & week0 & week1 & week2 & week3 & week4 & week5 & week6 \\
\hline Nanglai-worm & $180.66 \pm 6.00$ & $220.00 \pm 8.16$ & $300.00 \pm 7.63$ & $310.33 \pm 7.14$ & $320.66 \pm 6.14$ & $350.33 \pm 5.57$ & $360.00 \pm 3.65$ \\
Sumrong-worm & $181.66 \pm 3.07$ & $280.00 \pm 5.77$ & $310.00 \pm 4.47$ & $310.66 \pm 3.07$ & $340.66 \pm 3.33$ & $360.66 \pm 3.07$ & $380.33 \pm 3.33$ \\
Nangnoi-worm & $171.66 \pm 6.45$ & $260.00 \pm 4.08$ & $283.33 \pm 4.65$ & $303.33 \pm 2.23$ & $321.66 \pm 3.41$ & $370.33 \pm 1.82$ & $390.33 \pm 2.88$ \\
normal (0.5\% Tween 80) & $198.33 \pm 3.41$ & $255.00 \pm 4.65$ & $321.66 \pm 3.41$ & $348.33 \pm 4.65$ & $383.33 \pm 2.23$ & $423.33 \pm 2.23$ & $435.00 \pm 4.65$ \\
\hline
\end{tabular}

Table 3: Blood glucose level $(\mathrm{mg} / \mathrm{dL})$ of rats in sub-acute toxicity study $(\mathrm{n}=6)$

\begin{tabular}{cccccccc}
\hline $\begin{array}{c}\text { Treatment } \\
\text { 2,000 } \mathrm{mg} / \mathrm{kg} \text { b.w. }\end{array}$ & week0 & week1 & week2 & week3 & week4 & week5 & week6 \\
\hline Nanglai-worm & $104.50 \pm 10.08$ & $118.50 \pm 7.25$ & $98.50 \pm 6.20$ & $106.50 \pm 9.03$ & $79.50 \pm 4.85$ & $69.50 \pm 4.34$ & $81.50 \pm 5.12$ \\
Sumrong-worm & $101.16 \pm 5.13$ & $81.33 \pm 4.07$ & $79.33 \pm 4.07$ & $86.66 \pm 4.40$ & $65.50 \pm 3.35$ & $69.50 \pm 3.49$ & $89.66 \pm 4.67$ \\
Nangnoi-worm & $108.33 \pm 12.49$ & $115.66 \pm 24.99$ & $62.50 \pm 4.96$ & $102.66 \pm 13.66$ & $102.50 \pm 8.12$ & $101.33 \pm 13.50$ & $103.66 \pm 8.14$ \\
normal (0.5\% Tween 80$)$ & $79.16 \pm 5.18$ & $79.33 \pm 5.33$ & $93.50 \pm 6.11$ & $78.16 \pm 5.18$ & $98.50 \pm 5.81$ & $102.66 \pm 6.75$ & $92.00 \pm 5.38$ \\
\hline
\end{tabular}

Table 4: Blood chemistry parameters of rats in sub-acute toxicity study $(n=6)$ at $6^{\text {th }}$ week

\begin{tabular}{cccccccc}
\hline $\begin{array}{c}\text { Treatment } \\
2,000 \mathrm{mg} / \mathrm{kg}\end{array}$ & $\begin{array}{c}\text { BUN }(\mathrm{mg} / \\
\mathrm{dL})\end{array}$ & $\begin{array}{c}\text { Creatinine } \\
(\mathrm{mg} / \mathrm{dL})\end{array}$ & $\begin{array}{c}\text { Cholesterol } \\
(\mathrm{mg} / \mathrm{dL})\end{array}$ & $\begin{array}{c}\text { Triglycerides } \\
(\mathrm{mg} / \mathrm{dL})\end{array}$ & $\begin{array}{c}\mathrm{HDL} \\
(\mathrm{mg} / \mathrm{dL})\end{array}$ & $\begin{array}{c}\text { LDL } \\
(\mathrm{mg} / \mathrm{dL})\end{array}$ & $\begin{array}{c}\text { ALP } \\
(\mathrm{mg} / \mathrm{dL})\end{array}$ \\
\hline Nanglai-worm & $40.73 \pm 5.16$ & $1.16 \pm 0.13$ & $128.00 \pm 9.58$ & $138.33 \pm 33.89$ & $26.00 \pm 5.47$ & $78.00 \pm 12.09$ & $287.00 \pm 2.73$ \\
Sumrong-worm & $39.70 \pm 3.88$ & $1.06 \pm 0.05$ & $148.00 \pm 32.01$ & $177.50 \pm 24.64$ & $29.33 \pm 4.03$ & $81.00 \pm 3.57$ & $329.66 \pm 29.6$ \\
Nangnoi-worm & $40.30 \pm 5.91$ & $1.00 \pm 0.08$ & $129.00 \pm 13.88$ & $118.33 \pm 13.57$ & $32.66 \pm 4.92$ & $76.33 \pm 11.67$ & $285.00 \pm 16.23$ \\
$\begin{array}{c}\text { normal }(0.5 \% \\
\text { Tween } 80)\end{array}$ & $34.56 \pm 1.32$ & $0.90 \pm 0.08$ & $119.00 \pm 7.32$ & $133.00 \pm 5.16$ & $30.00 \pm 6.26$ & $62.83 \pm 7.27$ & $273.00 \pm 14.6$ \\
\hline
\end{tabular}

Table 5: Hematological parameters of rats in sub-acute toxicity study $(n=6)$ at $6^{\text {th }}$ week $^{\text {a }}$

\begin{tabular}{cccccc}
\hline $\begin{array}{c}\text { Treatment } \\
2,000 \mathrm{mg} / \mathrm{kg}\end{array}$ & $\begin{array}{c}\text { WBC } \\
\left(\text { cells } / \mathrm{mm}^{3}\right)\end{array}$ & $\begin{array}{c}\mathrm{RBC} \\
\left(10^{6} \mathrm{cell} / \mathrm{mm}^{3}\right)\end{array}$ & $\begin{array}{c}\mathrm{Hb} \\
(\mathrm{g} / \mathrm{dL})\end{array}$ & $\%$ Hct & $\begin{array}{c}\text { Platelet } \\
\left(\text { cells } / \mathrm{mm}^{3}\right)\end{array}$ \\
\hline Nanglai-worm & $3933.34 \pm 361.40$ & $8.20 \pm 0.88$ & $15.30 \pm 6.85$ & $45.66 \pm 3.14$ & $654000 \pm 12521$ \\
Sumrong-worm & $4333.00 \pm 223.62$ & $9.40 \pm 0.88$ & $17.96 \pm 1.61$ & $53.66 \pm 4.50$ & $670666 \pm 58578$ \\
Nangnoi-worm & $4332.34 \pm 119.10$ & $8.33 \pm 0.62$ & $17.73 \pm 1.22$ & $52.67 \pm 3.61$ & $679333 \pm 84177$ \\
$\begin{array}{c}\text { normal }(0.5 \% \\
\text { Tween 80) }\end{array}$ & $5166.00 \pm 310.66$ & $8.23 \pm 0.41$ & $16.50 \pm 1.84$ & $47.36 \pm 9.68$ & $764000 \pm 51666$ \\
\hline
\end{tabular}


Toxicity and Antioxidant Effect of Silkworm

Table 6: Antioxidant activity of Thai silkworm powders from three races

\begin{tabular}{cccc}
\hline Races & $\begin{array}{c}\text { DPPH } \\
\left(\mathrm{IC}_{50} ; \mathrm{mg} / \mathrm{mL}\right)\end{array}$ & $\begin{array}{c}\text { ABTS } \\
\left(\mathrm{IC} C_{50} ; \mathrm{mg} / \mathrm{mL}\right)\end{array}$ & $\begin{array}{c}\text { FRAP } \\
(\text { Trolox equivalent; } \\
\mathrm{mmol} / \mathrm{mL})\end{array}$ \\
\hline Nanglai & $57.08 \pm 5.32^{\mathrm{b}}$ & $123.08 \pm 13.32^{\mathrm{b}}$ & $255.20 \pm 36.98$ \\
Sumrong & $39.54 \pm 1.08^{\mathrm{b}}$ & $131.87 \pm 11.00^{\mathrm{b}}$ & $248.83 \pm 22.45$ \\
Nangnoi & $42.41 \pm 2.65^{\mathrm{b}}$ & $146.40 \pm 12.12^{\mathrm{b}}$ & $243.44 \pm 37.25$ \\
Ascorbic acid & $5.268 \pm 0.57^{\mathrm{a}}$ & $13.38 \pm 0.33^{\mathrm{a}}$ & - \\
\hline
\end{tabular}

The different letters $(\mathrm{a}, \mathrm{b})$ within a column show statistical differences $(\mathrm{p}<0.05)$

\section{DISCUSSION}

\section{The Acute and Sub-Acute Toxicity}

For the acute toxicity study, rats were administered with single dose of $5^{\text {th }}$ instar, $3^{\text {rd }}$ day silkworm powder of 3 races at doses of $1,000,1,500$ and $2,000 \mathrm{mg} / \mathrm{kg}$ body weight. The behavior and body weight were recorded at 0,7 , and 14 days, respectively. For the sub-acute toxicity study, rats were administered with silkworm powders from three races at dose of $2,000 \mathrm{mg} / \mathrm{kg}$ body weight, every 2 days for 6 weeks. The result showed that no signs of toxicity or abnormalities in rats, such as seizures, vomiting, ataxia, lethargy, loss of appetite had been observed. This study is the first report on acute and sub-acute toxicities of Thai silkworms. In addition, there were only studies on the nutritional values of silkworm powder, reporting the main components of a protein about $40 \%$ in Indian silkworm. ${ }^{16}$ The protein components were not different from normal food resulting to low toxicity. Similar to the studies of Mondal et al, ${ }^{17}$ the substances in the silk powder were about 16-18 amino acids. The study of Ninpetch et $a l^{18}$ analyzed the protein and lipid contents of the fifth instar mulberry silkworm (Bombyx mori L.) for substitution of protein from meat. Three silkworm races (Jim thompson, Nanglay and Thai hybrid) showed a rich source of protein. Jim Thompson race had $68.97 \%$ of protein, Nanglay race had $55.55 \%$ of protein and Thai hybrid race had $54.19 \%$ of protein.

\section{The Antioxidant Activity}

The antioxidant study indicated that silkworm powders were not significant difference in all groups of samples in three assays (DPPH, ABTS and FRAP). However, significant difference had been observed comparing with ascorbic acid. Antioxidant activities of mulberry silkworm may derive from some pigments in cocoon shell sericin. The coloring components are associated with phenolic compounds in the leaves of mulberry (Morus alba L.), the major feed for mulberry silkworm larvae. The two main pigments responsible for cocoon color are ether-soluble yellowish carotenoids and water-soluble green flavonoids. ${ }^{19-20}$ The studies of Tamura et al ${ }^{19}$ isolated quercetin 5-glucoside, quercetin 5,7,4'- triglucoside and quercetin derivatives from the yellow-green cocoon shell of MultiBi race. The previous study showed that there are several native races of silkworm in Thailand with various color of cocoon shell. The most common native Thai silkworm is Nangnoi with intent yellow, while the color of cocoon shell from other races are varied from white to green yellow. Flavonoid compounds are also responsible for antioxidant properties of mulberry silk cocoon. The studies of Butkhup et al ${ }^{21}$ showed that the strong correlation between total active ingredients (phenolics and flavonoids) and antioxidant activities (DPPH, ABTS and FRAP assay) had been observed in Thai silk sericin.

\section{CONCLUSION}

Acute and sub-acute toxicities of silkworms on hematological parameters and lipid profiles had not been observed. Silkworms also present antioxidant capacities.

\section{ACKNOWLEDGEMENT}

The authors would like to thank the National Research Council of Thailand (NRCT) for the financial support.

\section{CONFLICT OF INTEREST}

Authors declare no conflict of interest.

\section{ABBREVIATIONS USED}

BUN: blood urea nitrogen content; Creatinine: creatinine phosphate content; Cholesterol: blood cholesterol content; Triglycerides: blood triglyceride content; HDL: high density lipoprotein cholesterol; LDL: low density lipoprotein cholesterol; ALP: alkaline phosphatase; WBC: white blood cell content; RBC: red blood cell content; Hb: hemoglobin; \%Hct: \%hematocrit; Platelet: platelet content.

\section{REFERENCES}

1. Quan GX, Mita K, Okano K, Shimada T, Ugajin N, Xia Z et al. Isolation and expression of the ecdysteroid-inducible angiotensin-converting enzyme-related gene in wing discs of Bombyx mori. Insect Biochem Mol Biol. 2001;31(1):97-103.

2. Hu D, Liu $Q$, Cui $H$, Wang $H$, Han $D, X u H$. Effects of amino acids from selenium rich silkworm pupas on human hepatoma cells. Life Sciences. 2005;77(17):2098-110.

3. Li BC, Zhang SQ, Dan WB, Chen YQ, Coa P. Expression in Escherichia coli and purification of bioactive antibacterial peptide ABP-CM4 from the Chinese silk worm, Bombyx mori. Biotechnol Lett. 2007;29:1031-6.

4. Jacob JR, Mansfield K, You JE, Tennant BC, Kim YH. Natural iminosugar derivatives of 1-deoxynojirimycin inhibit glycosylation of hepatitis viral envelope proteins. J Microbiol. 2007;45(5):431-40.

5. Manosroi A, Boonpisuttinant K, Winitchai S, Manosroi W, Manosroi J. Free radical scavenging and tyrosinase inhibition activity of oils and sericin extracted from Thai native silkworms (Bombyx morı). Pharm Biol. 2010;48(8):855-60.

6. Raghavendra R, Neelagund S, Kuluvar G, Bhanuprakash V, Revanaiah Y. Protective effect of partially purified $35 \mathrm{kDa}$ protein from silk worm (Bombyx mori) fecal matter against carbon tetrachloride induced hepatotoxicity and in vitro anti-viral properties. Pharm Biol. 2010;48(12):1426-31.

7. Sumranpath K, Aungsuratana A, Auttathom T, Poramacom N. Existing condition of commercial sericulture production in Northeastern Thailand. Kasetsart $J$ (Social Sciences). 2015;36:155-64.

8. Heo HS, Choi JH, OH JJ, Lee WJ, Kim SS, Lee DH, et al. Evaluation of general toxicity and genotoxicity of the silkworm extract powder. Toxicol Res 2013; 29(4):263-78

9. Yatsunami K, Murata K, Kamei T. 1-Deoxynojirimycin content and alpha-glucosidase inhibitory activity and heat stability of 1-deoxynojirimycin in silkworm powder. Food Nutr Sci. 2011;2(02):87-9.

10. Ryu KS, Ahn MY, Lee HS, Kim I, Kim JW, Kim SH. The tonic effect of the extract from male silkworm (Bombyx mori L.) pupae on rats. Int J Indust Entomol. 2002;5(1):123-6.

11. Kiran GR, Raju AB. Antiobesity effect of Plytolacca berry in rats. Env Exp Biol. 2014;12:95-9.

12. Chaimum-aom N, Chomko S, Talubmook C. Toxicology and oral glucose tolerance test(OGTT) of Thai medicinal plant used for diabetes control, Phyllanthus acidus L. (EUPHORBIACEAE). Pharmacogn J. 2017;9(1):58-61.

13. Phadungkit M, Rattarom R, Rattana S. Phytochemical screening, antioxidant, antibacterial and cytotoxic activities of Knema angustifolia extracts. J Med Plants Res. 2010;4(13):1269-72.

14. Joshi RK. Chemical composition, in vitro antibacterial and antioxidant activities of the essential oils of Ocimum gratissimum, O. sanctum and their major constituents. Indian J Pharm Sci 2013;74:457-62.

15. Benzie IFF, Strain JJ. The ferric reducing ability of plasma (FRAP) as a measure of "Antioxidant Power": The FRAP assay. Anal Biochem. 1996;239(1):70-6.

16. Trivedy K, Kumar SN, Qadri SMH. Comparative study of major nutritional component of defatted and normal pupal powder of silkworm, Bombyx mori. Indian J Seri. 2011;50(2):188-90.

17. Mondal M, Trivedy K, Kumar SN. The silk proteins, sericin and fibroin in silkworm, Bombyx mori Linn., - a review. Caspian J Environ Sci. 2007;5(2):63-76.

18. Ninpect $U$, Sroysri $C$. Proximate protein and lipid content of fifth instar larvae of the 
mulberry silkworm (Bombyx mori L.). Kamphaengsean Acardemic. J 2007;5(1):16-9.

19. Tamura Y, Nakajima K, Nakayasu K, Takabayashi C. Favonoid 5-glucoside from the cocoon shell of the silkworm, Bombyx mori. Phytochemistry. 2002;59(3):275-8.

20. Kiyotaka N, Kenta O, Ohki H, Kimura T, Miyazawa T, Hori M. Determination of iminosugars in mulberry leaves and silkworm using hydrophilic interaction chromatography-tandem mass spectrometry. Anal Biochem. 2010;404(2):217-22

21. Butkhup L, Jeenphakdee M, Jorjong S, Samappito S, Samappito W, Butimal J. Phenolic composition and antioxidant activity of thai and Eri silk sericins. Food Sci Biotechnol 2012;21(2):389-98.

\section{GRAPHICAL ABSTRACT}

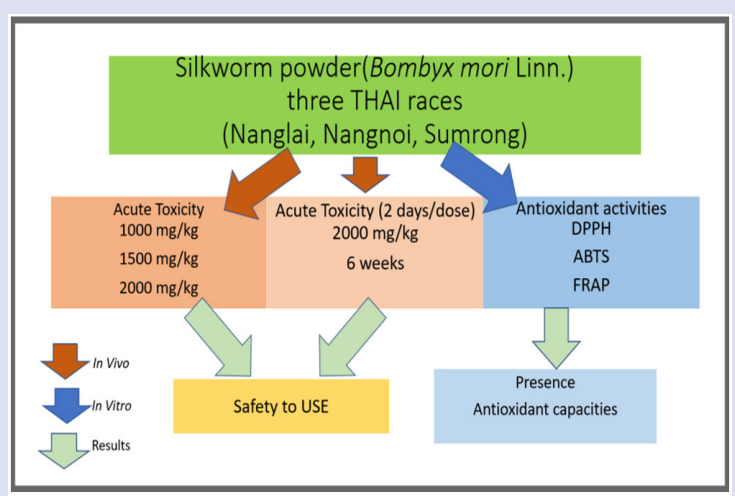

\section{HIGHLIGHTS OF PAPER}

- The no acute toxicity in rats by single dose oral administration presented that the high dose at a concentration of 2,000 $\mathrm{mg} / \mathrm{kg}$ body weight.

- The sub-acute toxicity in $2,000 \mathrm{mg} / \mathrm{kg}$ body weight for 6 consecutive weeks had no toxicity.

- The silkworm powders present antioxidant activity in three assays (DPPH, ABTS and FRAP).

\section{ABOUT AUTHOR}

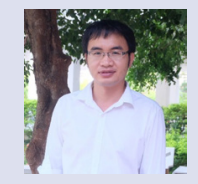

Mr. Surapong Rattana: Obtained his M.Sc. degree in 2012 from Faculty of Pharmacy, Mahasarakham University, Thailand. Currently, He is Ph.D candidate in Biology major, Faculty of Science, Mahasarakham University, Thailand. Mr. Rattana is working on various aspect of medicinal plant related separation and isolation of both pure active compound and crude drug from herb for toxicity and biological activities test to finding therapeutic valuable of medicinal plant.

Cite this article : Rattana S, Katisart T, Sungthong B, Butiman C. Acute and Sub-acute Toxicities of Thai Silkworm Powder (Bombyx mori Linn.) From Three Races in Male Wistar Rats and In vitro Antioxidant Activities. Pharmacog J. 2017;9(4):541-5. 